第70回日本内科学会請演会（1973年）

\title{
シンポジウム＼cjkstart診断学の変遷と展望
}

（2）情報工学の立場からみた診断過程

大阪府立成人病センター医用工学開発室

高橋 隆

\section{SYMPOSIUM ON HISTORICAL ASPECT OF DIAGNOSTICS AND ITS FUTURE}

(2) MEDICAL DIAGNOSIS FROM A VIEW POINT OF INFORMATION ENGINEERING

Takashi Takahashr, Ph.D.

The Center for Adult Diseases, Osaka

\section{I. 情報科学のあゆみと医学}

今日の情報科学の発展はめざましいが，その歴 史をふり返るとウィーナの提唱したサイバネティ クスに端を発する．彼は，通信・制御・統計学の 三つを中心とした一連の諸問題が，対象が機械で あつてす生体であつても，本質的な面は共通の概 念と方法とで統一的に記述され，説明されらるも のであることに気づき，1945年に生物学と工学の 境界領域の学問として，ギリシャ語の船の操舵手 といら意味からとつたサイバネティクスなるもの を提唱した。これは，「情報」と「制御」の立場か ら生物学と工学の両分野を見直し, 総合的な科学 思想を与えることになつた，彼はまたサイバネテ ィックス提唱以前に，今日の電子計算機について の設計の基本方針をる示し，1946年にはペンシル バニア大学で世界最初の電子計算機ENIAC (Electronic Numerical Integrator and Computer)が誕 生した。これには真空管が約 18000 本使用されて いたという，そして1948年にはシャノンにより確 率的な概念を基礎とした情報理論が完成，以後， 加速度的に図1飞示すような理論が展開され，今 日の情報科学が形成された。

情報科学は，機槭・生体扔よび人間社会に掠け

\begin{tabular}{|c|c|c|c|}
\hline & 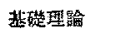 & 応用理喻 & $\begin{array}{l}\text { 応男技街 } \\
\text { (医学分野) }\end{array}$ \\
\hline サイバネテイクス & 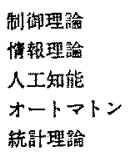 & 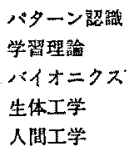 & 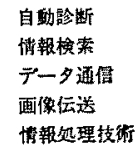 \\
\hline 子却算機 & 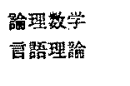 & $\begin{array}{l}\text { 機柀籶䣰 } \\
\text { OR } \\
\text { システム工学 }\end{array}$ & 数值計第 \\
\hline
\end{tabular}

図 1。筒報科学

る情報の生成・伝達・改造・蓄積・利用について の一般原理を考究する基幹科学であり，図1の右 欄にも示したように，医学との関連もきわめて深 いそれは，サイバネティックスの本質が医学と の関連が深いことる大さな理由のひとつである が，さらに，最近の医学に和けるセンサー類の飛 躍的発展により，医学情報が爆発的に増大し，旧 来の医学的態勢では対処しきれなくなつた必然の 帰結であるとも考觉られる。

\section{II. 診断過程の客観化}

阪大・古川によると，診断とは特定の患者につ いての最適の医療行為を決定するための論理過程 であるという。東大・高橋によると，その諭理過 程は主訴を背景とした解析計画に始まり，情報収 
集，次いで得られた情報をもとに学識と経験によ つて打立てられた論理に照らした病気の推定，招 よび病気の分離度，見逃しの危険，存在頻度など を考慮した上で，最終的に病名決定を行なら一連 の過程であるという，そして，分離度が，得た情 報の範囲内で不十分なときには決定を保留し，新 たな解析計画に基つく情報収集にもどる。そし て，满足のゆく分離度が得られるまで，このフィ ードバックルーブを远つて病気の推定を行なう。

また，日本医師会の藤沢は，診断の論理は，フ ィードバックループを含む，情報収集，処理，仮 説設立，扣よび診断決定に到る主過程から成り立 つとして，䛦断過程を，直観診断法，ハターン診 断法, 系統診断法, 症候診断法, 消去診断法, マ トリックス診断法，および治療診断法の七つに分 類している.

このような診断過程を工学的見地より考察する と，一種のパターン認識過程であるとみることが できる.ここで，パターンとはひとつの概念であ り，多次元情報空間に扣いて確率分布する集合の 抽象と考える，㹟義には空間的な物理量を伴うい わゆる図形であり，広義には病気などのようなス トカスティックな変量で表わされる事象をさす。 また，パターン認識とは，与えられた信号パター ンを見て，それが属すべきカテゴリに対応づける こと，またはどのカテゴリにも属さなければ竬却 することである。したがつて，バターンそのもの は外界に生起する様々な事象一般であり，時間拉 よび情報を含む空間上に広がりをむつ多变量で表 現される互に異質な事象であるが，認識はそれら を情報処理といら側面からとらえることにより等 質に取扱扝うとするるのである.

\section{パターン認識の過程}

パターン認識の一般的過程は特徵抽出と識別と に分けられる。一般にパターン空間Dの次元数は 非常に高く，パターン信号先のものをとり扱つ て，それが属す集合全体についてパラメータの全 てを比較照合することは困難である，そこで，そ のような網羅的方法を避けるため，各カテゴリを
代表する標準パターンを記述する最少限の特徽バ ラメータを選び出す。これを特徽抽出という.す なわち，パターン空間Dの特徵空間 Sへの写像が 特徵抽出である。一方，識別とは，観測された特 徵パラメータから，それがどの標準パターンに最 む類似度が高いか，すなわちパターン空間Dのど のカテゴリに属すべきかを推定する過程である. したがつて，一般には，識別それ自体パターンの 本質とは無関倸にとり扱えるが，疾病を対象とす る場合には，特別な留意が必要となろう。

\section{診断の工学的モデ}

パターン認識の概念を用い診断をモデル化する と図 2 に示すよらになる。

実際の診断は，主訴に含まれる症候の取得に端 を発して，先に示した七つの分類に従つて進行す るわけであるが，これらをまとめてモデル化する と同図のようになる。このモデルの特徽は識別過 程に連想機能を有していることである，すなわ ち，まず患者の主訴は特徵抽出過程を経て識別過 程に入り，ここの連想機能によつて想定される標 準パターン(典形的な疾病；ひとつは限らない) が描かれる．これによつて規定されるいくつかの 特徵空間を满たすための情報が次に収集される。 このようにしてでき上つた特改空間 Sをむとに， 医師の学識と経験によつて得たアルゴリズムに従 つて識別が行なわれる。識別が満足すべき分離度 を与えないときは，新たな症候の追加に努力をは らう.すなわらフィードバックがかけられ，満足

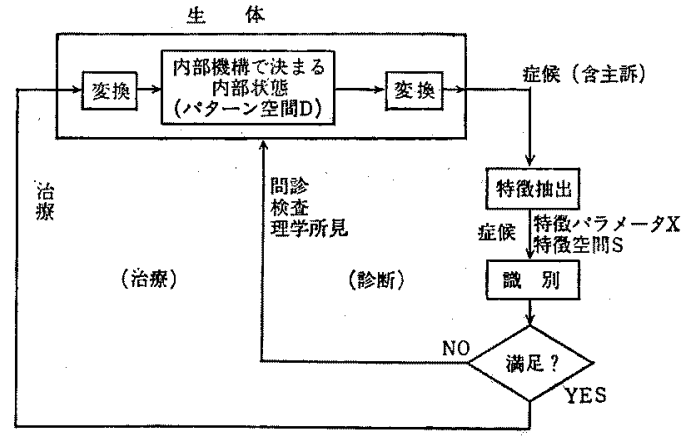

図 2.誩断の工学的モデル 
すべき分離度を得るまで抽出，識別の過程をくり 返す．直観診断法やパターン診断も，識別過程に 連想機能をむたせることにより，このモデルで統 一的に取り扱うことが可能である.

\section{医学情報の特性}

診断を電子計算機を用いて行なおうとすると， 用いる医学情報の特性が問題となる. 診断への有 効性から備えるべき条件は，

妥当性一対象とする疾病の情報が，それに必要 かつ十分含まれていること．象全体を知る目 的に対し，尻尾や足だけ触れていたのではだ め.

信頼性一それが客観性に富み，から再現性を有 すること. 主観的，文学的表現による病歴 や，品質管理の不充分な検査データ等はだ め.

感度一病状がある範圕で少し变動したとき，こ れに応じて情報に鋭敏隹变化がでること．一 方, 実際に得られている医学情報の特性は, 多重性一情報の形態が，医師の主観に基つくく 記述的なるの, 形態学的なるの, 計量的なも の，アナログ波形等, 種々雑多.

圥長性一いくつかの症候を集めると，同一原因 に基づくと思われるすのがある。つまり情報 の意味が做かよつているものをとりそろえて いる.たとえばGOTとGPTなど.これは 診断の信頼性を保つ意味ではある程度は必要 たが，計算機猃断の立場からは，意味の重複 はなるべく少なくしたい。

不確定性一ひとつの症候がひとつの疾病に対応 しない，たとえば発熱や白血球数上昇など。 不完全性一種々な事情により必要な情報がそる つていないことがある，すなわち情報の欠損 のもとで診断を下さねばならないことがある （連想記憶に依存）。

経時的無定態性一計量的データにしろ，アナロ グ波形にしろ，定常状態において計測して も，一定值あるいは一定波形を示さず確率的 変動を伴つている.

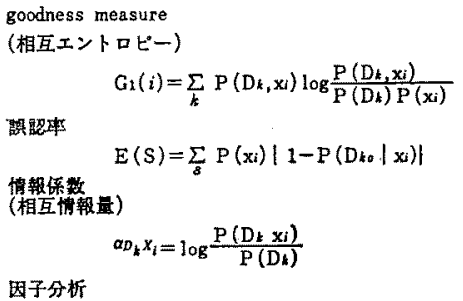

図 3、特徵の標価

階層性一種々な側面からの階層性がある。など である。

このような医学情報をるとに，診断過程を電子 計算機によって 行なら場合には，先に示したよ らに，やはり特徵抽出と識別とに分けて行なわれ る.

\section{特徴の評価}

一般に，識別過程がパターンの性格にほとんど 左右されない部分であり，パターン一般に対して 共通に論ずることができるのに対し，特徵抽出過 程は，識別のための素材を個々の具体的な現象か ら抽出してくる部分であるから，パターン空間の 特徵を十分反映するるのでなければならない，換 言すれば，症候群の中からどれとどれを選へば能 率上く疾症を分離できるかということである。あ るいは，ある症候を観测したとさに，それが分離 されるべき疾病についての情報をどの程度含んで いるかといらことを定量的に標価しておく必要が あるといらことである.

この標価法としては図 3 に示すように, 症候 S と疾病 Dの間の情報量にかんすする相互エントロ ピーや情報係数，あるいは誤認率などが用いられ ている.たとえば，goodness measureは，症候Xi の生起確率が個々に固定されているときに，相互 情報量の最大值を与える症候iが症候空間 $\mathrm{S}$ を最 もよく反映するパラメータとして選択されるべき ことを示している.

また，症候 S のて長性を少なくするために因子 分析法が用いられる。したがつて，因子分析法で まず症候を分類しておき，その後，先の湘度で標 価すべきと考えられる。 


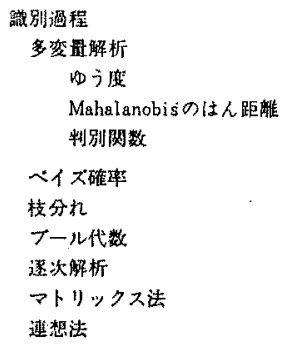

困 4. 識别過程

\section{識別過程}

識別は，それ自体パターンの本質とは無関係に とり扱えるわけであるが，医師の診断のアルゴリ ズムが明確でないために体系だつた理諭楧成はな されていない，個々の研究者が，場合に応じて各 種の数学理論や工学的手法を導入し,アルゴリズ ムの形成に努力をはらつている．云の代表的なる のを示すと図 4 のよらになる.

\section{II. 診断への新しい工学応用 (TV技術を用い た遠隔医療）}

従来の医療はman to manつまりDr. to Patient の関係の維持を大原則として，医療の場を病院・ 医院等に限定し，物理的空間に束縛された形で進 められてきた. しかしながら社会的諸情勢は，医 療の「場」の限定を望まず，広く情報化社会シス テムの中に融合することを求めている. その具体 的な例のひとつはいわゆるAMHTSであり，いま ひとつは遠隔医療である.

医療に特ける物理的空間の超越を求める遠隔医 療の対象となるすのは現在のところ僻地, 救急, 船舶などであり，さらに将来は航空機，口ケッ 卜，むるいは人工衛星, 惑星等に広がる可能性が ある.

これらに対して，情報工学の成果である画像伝 送技術やデータ通信技術を応用すれば，医療に括 ける空間の制䄪を打破り，かつ，最少限のman to manを維持しつつ, 医療の「場」を病院, 医院 等から遠方に伝送することが可能であると考えら れる、すなわち，CA T V等の T VKよる画像通 信を中心とした情報システムが遠隔医療に有效で

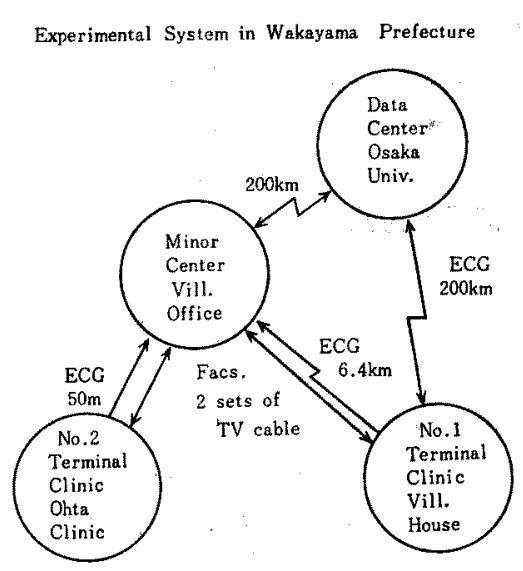

因 5.僻地における遠隔医嫄の実驗システム

あることが期待される.

筆者らは，この期待に基づき，和歌山県の僻地 におもむいて 2 度にわたり実験を行なつた。実験 システムは，図 5 に示すよらに，僻地の保健機関 としての端末検診所（保健婦により地域住民の健 康管理を行なう), 僻地の最寄りの医療機関とし てのサブセンター（医師により地域住民の健康管 理を行なう),およびデータセンター(地域の医療 情報センターで，データバンクの機能を持つ）か ら成り立つ.これらの相互間を，図に示すように， 2 本の T Vヶープルと電話回線を設置し, 互に離 れている医師と患者の間に双方向の画像伝送と， E C G 伝送を行なつた。この実験によつて, 理学 所見の一部を除いて, 診断に必要な情報の大部分 は伝送可能であるとの見通しを得，かっ，TVを

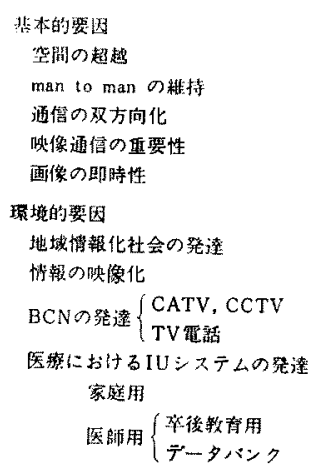

図6、医療に的ける画像通信発展の要因 
通じてサブセンター側から端末検診所側への種々 な技術指導をる可能であり，最新の技術を僻地に 持込又可の見通しを得た。

このよらに，TVを利用した画像伝送は医療に 導入されて遠隔診断に大いに寄与することが期待 される，その基本的要因と環境的要因とを図 6 K 示す.

\section{おわりに}

電子計算機を医学に利用することの利益のひと つに，医師がひとうの判断を下すに際して，従来 は医師が自分の経験を大脳内で険索していた過程 を機械におきかえ，客観性のある大量の病歷を正 確に恰索し，医師に必要な情報をりアルタイムで
提示して，その判断を助けることをあげることが できる。この観点にたてば，患者の限られた情報 から，従来の病理学的診断名にはそれほどこだわ らず，その時点で医師のとるべき戦略を提示す るような猃断システムが考劣られてよいように思 う。つまり，積似した症候をるつ疾病を過去の病 歴ファイルを唡索し，その時施した何種類かの手 とその経䋨について，治愈率，生存率等の形で表 示して，今，どの手を選ぶべさかを医師に判断さ せるよらなシステムである。すなわち，専門医と 適中率を競う computer diagnosisではなく，医師 と協調する computer aided diagnosisが必要なので はなかららか。 